\title{
NOTA SOBRE A MOLESTIA DE VIRUS DO FUMO DENOMINADA FAIXA DAS NERVURAS (')
}

\author{
A. S. Costa \\ e \\ R. Forster
}

\section{INTRODUÇ $\tilde{A} O$}

Esta moléstia foi recentemente descrita por Kramer \& Silberschmidt (12). O virus causador da faixa das nervuras é colocado por estes autores dentro do grupo $\mathrm{Y}$ e mais próximo ao virus do "veinbanding" dos autores americanos, um dos componentes do "rugose mosaic" da batatinha (9).

Uma moléstia do fumo que é indubitavelmente semelhante à faixa das nervuras, vem sendo por nós observada há já alguns anos nas plantações de fumo efetuadas na Estação Experimental Central em Campinas. Uma pequena nota a seu respeito foi apresentada no nosso relatório para $1939 / 40$.

É possivel que a moléstia por nós estudada seja causada por "strains" ligeiramente diferentes do encontrado por Kramer \& Silberschmidt. Contudo, comparando-se as propriedades do "strain" do virus estudado por aqueles autores e dos "strains" com que trabalhamos, chega-se a uma conclusão: a-pesar das diferenças entre os "strains" do virus propriamente dito, a moléstia é a mesma.

Inicialmente, a faixa das nervuras foi estudada em conexão com as variedades do grupo Sumatra, pois estas, em geral, reagem de uma maneira particular ao virus, dando formação a lesões necróticas brancas, alem dos outros sintomas.

Os autores citados acima, descreveram pormenorizadamente a faixa das nervuras. Entretanto, vamos apresentar tambem os nossos trabalhos e observações, feitos independentemente, apontando ao mesmo tempo os pontos de similitude e de dissemelhança, à medida que eles forem sendo discutidos.

(1) - O manuscrito deste trabalho foi apresentado ao dr. Karl Silberschmidt que sugeriu algumas modificaçc̃es, pelas quais deixamos aquí o nosso agradecimento. 


\section{IMPORTÂNCIA ECONÔMICA}

Kramer \& Silberschmidt (12) referem que observaram a faixa das nervuras em 10 plantas, num total de 50. Mais adiante frisam a importância que a ocorrência deste virus nás plantações de fumo e em hervas más possa vir a ter com relação às doenças da batatinha.

A faixa das nervuras foi encontrada até a presente data nas plantações de fumo efetuadas na Estação Experimental Central em Campinas e na Estação Experimental de Tupí. Na Estação Experimental de Limeira inspecionamos cuidadosamente algumas plantações de fumo numa ocasião em que a moléstia era prevalente em Campinas, mas sem encontrá-la. A sua ocorrência em outras localidades ainda não foi observada.

As nossas observações teem mostrado que a ocorrência deste virus do grupo Y pode assumir importância econômica nas plantações de fumo propriamente ditas, alem de apresentarem importância em relação à batatinha, como acima referido por aqueles autores.

A julgar pelas observações que temos efetuado na Estação Experimental Central, o número de plantas atacadas pela faixa das nervuras nas plantações de fumo é grande. Em certas épocas a percentagem de plantas afetadas atinge, praticamente, $100 \%$. Nas observações sobre esta moléstia, efetuadas nos ensaios de época de plantio, temos efetuado a contagem de plantas afetadas, de preferência nos lotes da var. Sumatra, por fornecer ela maior facilidade para identificação. Em outras ocasiões, contagens paralelamente efetuadas em lotes das variedades Amarelinho, Goiano e Sumatra, mostraram-nos que elas são mais ou menos igualmente suscetiveis.

No quadro seguinte reproduzimos alguns dos dados obtidos:

\section{QUADRO I}

PROTOCOLO DA FAIXA DAS NERVURAS NO ENSAIO DE ÉPOCA DE PLANTIO. ESTAÇAO EXPERIMENTAL CENTRAL $1942 / 41$.

VARIEDADE SUMATRA.

\begin{tabular}{c|c|c|c|c}
\hline \hline $\begin{array}{c}\text { Época } \\
\text { da trans- } \\
\text { plantação }\end{array}$ & $\begin{array}{c}\text { Data do } \\
\text { protocolo }\end{array}$ & $\begin{array}{c}\text { N. }{ }^{\circ} \text { de plan- } \\
\text { tas } \\
\text { examinadas }\end{array}$ & $\begin{array}{c}\text { N. de plan- } \\
\text { tas } \\
\text { afetadas }\end{array}$ & $\begin{array}{c}\% \text { da } \\
\text { moléstia }\end{array}$ \\
\hline $30 / 7 / 1941$ & $15 / 10 / 1941$ & 120 & 71 & 59,2 \\
$15 / 8 / 1941$ & $15 / 10 / 1941$ & 119 & 76 & 63,9 \\
$30 / 8 / 1941$ & $25 / 10 / 1941$ & 131 & 74 & 56,5 \\
$15 / 9 / 1941$ & $5 / 11 / 1941$ & 124 & 87 & 70,2 \\
$30 / 9 / 1941$ & $25 / 11 / 1941$ & 136 & 91 & 66,9 \\
\hline
\end{tabular}


Efetuamos tambem a contagem de plantas afetadas numa plantação da var. Sumatra, com cerca de meio hectare, realizada na Estação Experimental Central em 1941/42. O resultado obtido mostrou-nos que 34,5\% das plantas estavam afetadas pela faixa das nervuras.

Para muitas variedades de fumo, os danos causados pela faixa das nervuras são aparentemente ligeiros. A variedade Sumatra e outras que reagem tambem com necrose teem suas folhas qualitativamente bastante prejudicadas. Nada sabemos ainda sobre a influência que a moléstia possa ter sobre a seca dos fumos de estufa.

A forte reação necrótica apresentada pelas variedades do grupo Sumatra a este virus, diminue um tanto o seu valor como planta fornecedora de resistência para criação de variedades resistentes a viracabeça (13). Este fato deve ser levado em linha de conta nos planos de seleção visando a solução daquele problema.

Temos observado alguns casos em que esta moléstia parece contribuir para auxiliar a requeima facilitando aparentemente a infeção. Isto foi observado em plantas da var. Virginia Bright.

A facil disseminação da moléstia, que temos observado em plantações de fumo, mostra que as relações entre esta e o seu vetor já se acham bem estabelecidas. Este fato aumenta a sua importância econômica com relação ao fumo, batatinha e outras plantas econômicas suscetiveis.

\section{PLANTAS AFETADAS}

Todas as variedades de Nicotiana tabacum até agora observadas se teem mostrado suscetiveis à faixa das nervuras. Entre elas podemos citar as seguintes: Sumatra, Virginia Bright, White Burley, Goiano, Kentucky, Turkish, etc. Um estudo da suscetibilidade relativa das diferentes variedades ainda não foi feito.

Por meio de inoculações artificiais já transmitimos a moléstia às seguintes espécies de Nicotiana, que já tinham sido usadas com resultados positivos nos estudos de Kramer e Silberschmidt: $N$. rustica L., N. sylvestris Speg., e N. Langsdorfii Schrank, e alem disso ainda às espécies: $N$. glutinosa L., $N$. repanda Willd., $N$. longiflora Cav., $N$. quadrivalvis Fursh, $N$. digluta Clausen \& Goodspeed (*), $N$. angustifolia (**), N. Gossey Domin, N. sanderae Hort. ex W. Watson, $N$. nudicaulis S. Wats e N. paniculata L.

$\left(^{*}\right)$ - Kramer \& Silberschmidt referem ter inoculado esta espécie mas, aparentemente, houve alguma confusão nesta afirmativa, pois a planta usada foi a mesma utilizada por Holmes (7) e recomendada por Johnson (8) para estudos sobre virus. A planta designada por estes autores não é $N$. digluta, mas sim o híbrido F. 1 entre $N$. tabacum × $N$. glutınosa que é auto-esteril. $N$. digluta é o alotetraploide deste cruzamento e é fertil.

$(* *)$ - $\bar{A}$ espécie aqú assinalada como $N$. angustifolia pertence, provavelmente, do grupo de $N$. alata. Com aquele nome foram as sementes recebidas da Division of Tobacco and Plant Nutrition, U.S.D.A. 
Alem das espécies acima citadas, infetamos, artificialmente, Solanum tuberosum L. Lycoparsicon erculentum Mill., L. pimpinellifolium Mill. e Cyphomandra betacea Sendt.

Mostraram-se imunes à moléstia sob as condições das nossas experiências, alem de Datura stramonium L. (já estudada por Kramer \& Silberschmidt), Nicotiana glauca Grah., Nicandra physaloides Gaertn., Solan:m nodiflorum, Lactuca sativa L., Brassica oleracea L., Vigna sinensis Endl. var. Black, Dolichor lablab L. var. purpurens e Solanum nigrum L..

\section{QUADRO II}

\section{LISTA DAS PLANTAS INOCULADAS}

\begin{tabular}{|c|c|c|}
\hline $\begin{array}{l}\text { Plantas afetadas que } \\
\text { mostraram sintomas }\end{array}$ & $\begin{array}{l}\text { Plantas afetadas que } \\
\text { não mostraram sintomas }\end{array}$ & $\begin{array}{l}\text { Plantas não } \\
\text { afetadas. }\end{array}$ \\
\hline $\begin{array}{l}\text { Nicotiana tabacum (1) } \\
N . \text { glutinosa (1) } \\
N . \text { rustica (1) } \\
N . \text { digluta (1) } \\
N . \text { repanda (1) } \\
N . \text { angustifolia (1) } \\
N . \text { Langsdorfii } \\
N . \text { quadrivalois } \\
N . \text { nudicaulis } \\
N . \text { syluestris } \\
N . \text { Gossey } \\
N . \text { Sanderae } \\
N . \text { longiflora } \\
\text { Lycopersicon esculentum (1) } \\
\quad \text { (3) } \\
\text { L. pimpinellifolium } \\
\text { Cyphomandra betacea } \\
\text { Solanum tuberosum }\end{array}$ & $\begin{array}{l}\text { N. paniculala (1) } \\
\text { Lycopersicon } \\
\quad \text { erculentum }\end{array}$ & $\begin{array}{l}\text { Datura stramonium (2) } \\
\text { Nicotiana glauca (2) } \\
\text { Nicandra physaloider (2) } \\
\text { Solanum nodiflorum (2) (4) } \\
\text { Lactuca sativa } \\
\text { Brassica oleracea } \\
\text { Vigna sinensis var. Black } \\
\text { Dolichos lablab var. purpurens } \\
\text { Solanum nigrum (2) }\end{array}$ \\
\hline
\end{tabular}

(1) De todas as espécies assinaladas, obtivemos o virus da faixa das nervuras em re. troinoculações para fumo.

(2) Destas espécies, as retroinoculações foram negativas.

(3) Lycopersicon esculentum em algumas séries tem mostrado sintomas tão ligeiros que podem passar quase despercebidos.

(4) De 22 plantas de $S$. nodiflorum inoculadas, apenas 1 mostrou sintomas de faixa das nervuras. Entretanto, não é possivel afirmar que se tratava da moléstia causada pelo virus da faixa das nervuras, pois não fizemos retroinoculações. 


\section{QUADRO III}

RESULTADO DOS ENSAIOS DE INOCULAÇAO

\begin{tabular}{|c|c|c|c|c|c|}
\hline \multirow[b]{2}{*}{ SUSCETIVEL } & \multirow{2}{*}{$\begin{array}{l}\text { Método de } \\
\text { inocula- } \\
\text { ção }\end{array}$} & \multicolumn{2}{|c|}{ N. ' DE PLANTAS } & \multicolumn{2}{|c|}{ SINTOMAS } \\
\hline & & $\begin{array}{c}\text { inocula. } \\
\text { das }\end{array}$ & $\begin{array}{l}\text { infeta- } \\
\text { das }\end{array}$ & $\begin{array}{l}\text { Pri- } \\
\text { mário }\end{array}$ & $\begin{array}{l}\text { Secun- } \\
\text { dário }\end{array}$ \\
\hline 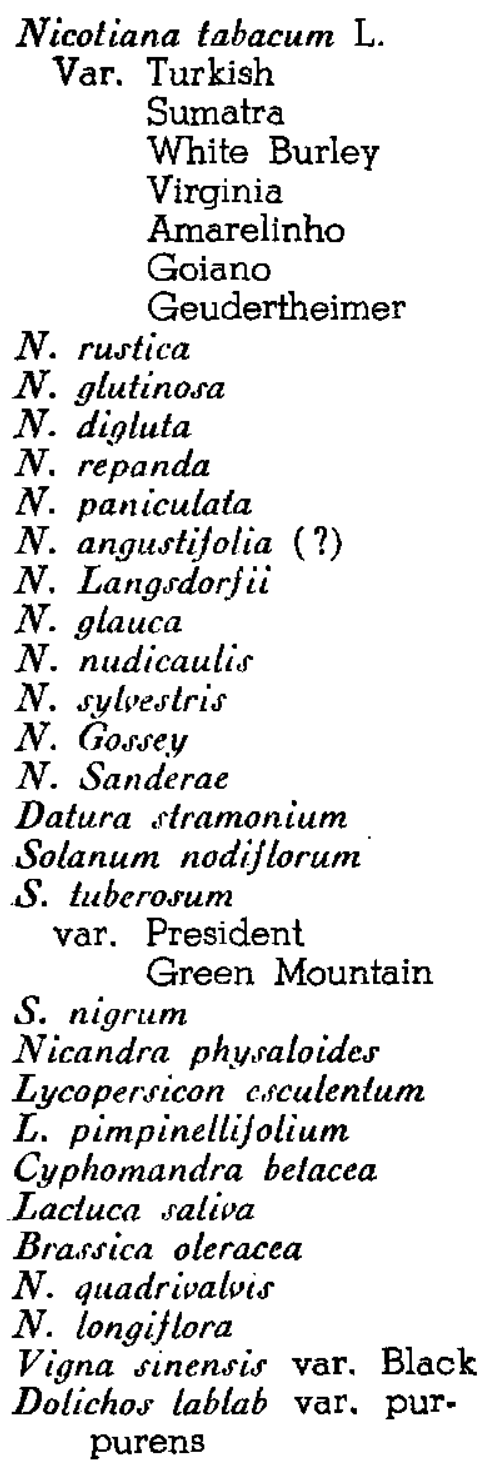 & 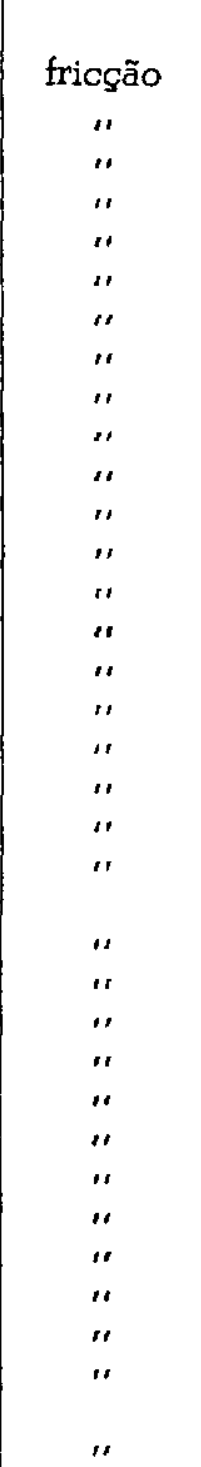 & $\begin{array}{r}286 \\
74 \\
19 \\
4 \\
25 \\
15 \\
10 \\
52 \\
34 \\
6 \\
6 \\
6 \\
10 \\
6 \\
12 \\
6 \\
6 \\
2 \\
2 \\
38 \\
22 \\
\\
2 \\
2 \\
16 \\
28 \\
16 \\
10 \\
6 \\
10 \\
10 \\
6 \\
12 \\
10 \\
10\end{array}$ & 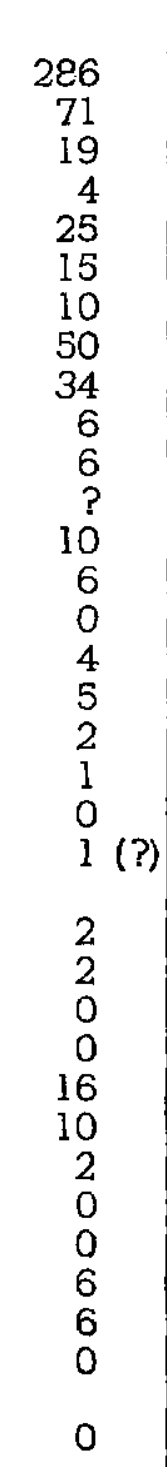 & 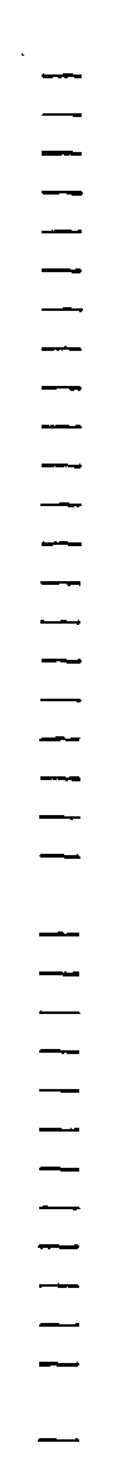 & 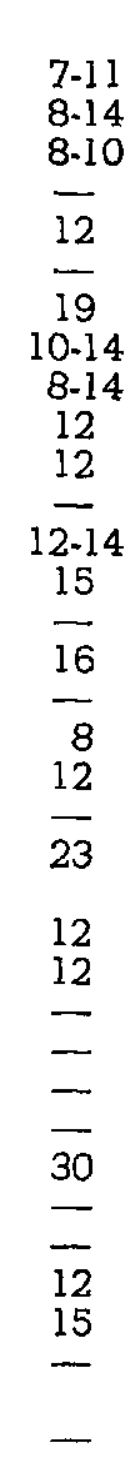 \\
\hline
\end{tabular}

\section{SINTOMATOLOGIA}

A faixa das nervuras é principalmente uma moléstia das plantas de fumo no campo. Ela se manifesta em geral na segunda metade do ciclo da vida das plantas. Ocasionalmente, já observamos a sua manifestatação em plantas ainda no viveiro.

A sintomatologia da moléstia causada por este virus em diferentes variedades de fumo pode apresentar ligeiras diferenças. De uma maneira 
geral ela se assemelha ao que tem sido descrito para as plantas de fumo afetadas por virus do grupo Y.

Kramer \& Silberschmidt (12) descreveram os sintomas da moléstia nas variedades Samsoun, Havana, White Burley, Sumatra, Kentucky e Amarelo do Rio Grande. A sintomatologia por nós observada concorda de um modo geral com a descrita por estes autores. Está, porem, em desacordo com as nossas observações a afirmação por eles feita, de que no campo, o quadro sintomatológico da moléstia é mais caraterístico pelo aparecimento das manchas verde-claras, redondas, ao passo que nas plantas inoculadas artificialmente a faixa das nervuras é o sintoma mais acentuado. Pelo que observamos, tanto no campo como nas plantas inoculadas artificialmente, as manchas cloróticas arredondadas são mais conspícuas, enquanto as plantas estão ainda numa fase de desenvolvimento vegetativo rápido. A faixa das nervuras é principalmente um sintoma tardio, se bem que, às vezes, se manifeste logo no início da infeção. Não sabemos tambem como explicar o fato daqueles autores não terem observado a presença de pintas necróticas brancas, associadas com a moléstia em certas variedades como a Sumatra.

Valleau \& Johnson (17) descrevem a moléstia causada pelo virus do "veinbanding" em plantas da var. Turkish. Esta descrição coincide perfeitamente com o que temos observado em plantas da mesma variedade, exceto quanto ao fato de não termos observado a queda das follhas já presentes na planta na ocasião da inoculação, a que se referem aqueles autores. Por outro lado, não observaram eles a presença das pintas necróticas que teem sido por nós observadas tambem nesta variedade.

Kohler (11), descrevendo os sintomas causados pelo virus $P$ em fumo Samsoun, relata um quadro sintomatológico bastante semelhante ao que temos observado em Turkish, exceto tambem quanto à falta de referência a sintomas de pintas necróticas brancas.

\section{Sintomas da faixa das nervuras em fumo (*)}

A primeira manifestação da moléstia é a palidez das nervuras das folhas novas: em plantas inoculadas este sintoma se manifesta a partir do sétimo dia. As folhas em seguida formadas mostram então uma clorose sob a forma de manchas arredondadas $\left({ }^{*}\right)$, ocorrendo nas ilhotas do

(") Os sintomas descritos são baseados na observação da moléstia em plantas da variedades Amarelinho, Goiano, Virginia, Sumatra e Turkish.

(**) A variedade Turkish é uma das que mostra os sintomas de manchas clorbticas arredondadas de uma maneira mais caraterística. 
parênquima ("vein-islets"). É preciso notar que a folha muito nova não mostra as manchas cloróticas; só depois de um desenvolvimento parcial é que elas se manifestam. De início, há uma tendência para que as manchas se manifestem primeiramente nas proximidades do ápice da folha. Em certos casos a clorose se manifesta como manchas indefinidas, apresentando toda a parte próxima ao ápice uma cor verde clara sem brilho.

À proporção que as folhas com manchas cloróticas vão aumentando a idade, as áreas cloróticas das ilhotas do parênquima tendem a aumentar até invadir toda a superfície entre as nervuras, respeitando somente pequenas faixas paralelas às nervuras e dando assim formação ao sintoma faixa das nervuras ("veinbanding"). Neste caso as faixas das nervuras são mais ou menos contínuas. Nem sempre, porem, há esse aumento em tamanho das áreas cloróticas. Em muitas plantas, as manchas cloróticas não sofrem transformação. Em certos casos podem-se observar folhas que mostram as pintas cloróticas, bem como áreas com faixa das nervuras, estas tambem se iniciando de preferência nas proximidades do ápice.

Alem do tipo já descrito de faixa das nervuras, há tambem uma outra forma na qual as faixas são de uma cor verde mais escura que o verde normal da planta. Neste tipo, as faixas são mais interrompidas do que no caso anterior.

Como já atrás referimos, as manchas cloróticas arredondadas são mais visiveis nas folhas de plantas em desenvolvimento vegetativo rápido. As faixas das nervuras são mais visiveis nas folhas adultas.

À medida que as plantas envelhecem, há uma diminuição na intensidade dos sintomas. Em plantas que já completaram o ciclo vegetativo, os sintomas são pouco acentuados.

Em certos casos, comparando-se plantas sadias com afetadas, verifica-se que estas apresentam, alem dos sintomas descritos, uma clorose fraca generalizada: as plantas são um tanto amarelas em comparação com as sadias. Reduções no tamanho da planta ou de partes da planta, se presentes, são muito ligeiras.

Algumas variedades de fumo, quando afetadas pela faixa das nervuras, mostram sintomas muito ligeiros, passando despercebidos quando examinados ligeiramente. Em nossas inoculações artificiais, a variedade Geudertheimer mostrou sintomas muito fracos e indistintos, podendo quase ser tomada como uma planta portadora.

$\mathrm{Na}$ maioria das variedades observadas, os sintomas se resumem então em palidez das nervuras, manchas cloróticas e faixa das nervuras. É fato digno de nota que algumas variedades, como as do grupo Sumatra 
e a varie dade Turkish, mostram, alem dos sintomas descritos, a presença de lesões necróticas, mais ou menos arredondadas, de cor avermelhada no princípio, mais tarde muito brancas. Estes sintomas necróticos são particularmente acentuados na variedade Sumatra (*).

As pintas necróticas brancas são mais severas nas plantas naturalmente afetadas. Manifestam-se com menos intensidade nas plantas inoculadas, mantidas em caixas à prova de insetos.

Observando-se as plantas da variedade Sumatra afetadas pela faixa das nervuras e já de idade adulta, verifica-se que as pintas brancas geralmente não ocorrem nas folhas mais inferiores. Ela principia a aparecer sempre da $3 .^{a}$ ou $4 .^{a}$ folha para cima. Isto mostra que a infeção se deu aproximadamente na época em que estas folhas se estavam desenvolvendo. É notavel que as folhas mais inferiores não apresentam pintas brancas, contribuindo este fato para indicar que os sintomas são causados por um virus e diferenciando a moléstia de alguma requeima de natureza criptogâmica.

A presença das pintas necróticas brancas que observamos em certas variedades poderia sugerir a hipótese de estarmos em presença de um complexo de virus. A nosso ver, este sintoma não foi ainda observado em associação com nenhum virus do grupo $Y$ quando sozinho em fumo. Alem disso, certos complexos de $\mathrm{X}+\mathrm{Y}$ causam sintomas necróticos em fumo que em certos casos lembram as nossas pintas necróticas brancas. A figura $2 \mathrm{C}$ de Valleau \& Johnson (17) representa uma folha de fumo da var. Turkish afetada pelo complexo "Sport necrosis" (mistura de virus "veinbanding" virus + "healthy potato virus"). Os sintomas nela representados se assemelham às pintas necróticas por nós observadas.

Sob o nome de "Speck-spot" Valleau \& Johnson (18) referem-se a uma moléstia causada por virus e que se assemelha bastante às nossas pintas brancas.

Alguma confusão pode tambem surgir entre os sintomas necróticos aquí descritos e aqueles presentes nas moléstias causadas por Botry ybasidium solani (Pril. \& Del.) Donk (2) e pelo virus da necrose branca ou couve (3). É, contudo, facil diferençá-los : No caso da moléstia causada por $B$. solani, as manchas necróticas são tambem arredondadas e em muitos casos de cor branca. No início são de uma aparência oleosa, o que não é o caso das pintas brancas. O tamanho das lesões é tambem maior. Esta moléstia é frequente no viveiro, mas rara no campo. Alem

(") Caso fique definitivamente provada esta reação particular da var. Sumatra ao virus da faixa das nervuras, ela poderá ser usada com vantagem como planta indicadora para este ou outros virus do grupo Y. $O \mathrm{dr}$. W. D. Valleau, a quem escrevemos a respeito deste sintoma, nos comunicou por carta ter observado frequentemente os mesmos sintomas nas plantas afetadas pelo virus do "veinbanding" ou Y. Todavia, os sintomas só se manifestavam em campo, não em estufa. 
disso, o exame microscópico de uma dessas manchas revela logo a presença de micélio de Rhizoctonia.

As pintas necróticas encontradas em associação com o virus da faixa das nervuras podem ser diferençadas daquelas presentes no quadro sintomatológico da necrose branca ou couve com muita facilidade: em primeiro lugar, no caso desta última moléstia, os sintomas se manifestam em, apenas, algumas folhas, as anteriores e posteriores permanecendo sem necrose. Alem disso, o tipo de necrose é mais linear (risca = "strea $k^{\prime \prime}$ ) e há tambem muitas vezes rugosidade e perfurações na mesma folha. A figura 5 ilustra a diferença entre os sintomas necróticos presentes nestas duas moléstias.

$\grave{A}$ luz dos fatos experimentais até agora observados, somos obrigados a concluir que as pintas necróticas brancas por nós observadas pertencem ao quadro sintomatológico causado pelo virus da faixa das nervuras em certas variedades de fumo. Apoiam este nosso ponto de vista os seguintes fatos:

1) O sintoma de pintas necróticas brancas por nós observado em associação à presença do virus da faixa das nervuras é bastante distinto e manifesta-se somente em certas variedades, como: Sumatra e Turkish. "Sport necrosis", em fumo, causa sintomas necróticos sob a forma de pintas, mas, alem disso, a necrose se manifesta sob outras formas e estes sintomas não constituem reação especial de certas variedades como no nosso caso.

2) Todas as plantas por nós observadas com as pintas necróticas brancas encerravam o virus da faixa das nervuras.

3) De uma maneira geral, pode-se dizer que todas as plantas das variedades Turkish e Sumatra quando afetadas, naturalmente ou em ensaios de inoculação, mostram as pintas necróticas brancas.

4) Nos ensaios sobre as propriedades físicas deste virus nunca observamos uma dissociação em dois virus distintos, o que seria de esperar no caso de um complexo.

5) $O$ virus $X$ não está associado ao virus da faixa das nervuras nos casos por nós estudados, pois nunca observamos sintomas sob a forma de anéis necróticos em fumo.

6) Plantas de Datura stramonium, inoculadas com os nossos "strains" de virus da faixa das nervuras, permanecem sem sintomas. Retroinoculações desta planta para fumo dão resultados negativos. A presença de X seria neste caso determinada não só pelo aparecimento de sintomas em $D$. stramonium como tambem, pela retroinoculação para fumo, nós obteríamos $X$ em estado puro (15). 


\section{Sintomas em Nicotiana glutinosa}

Kramer \& Silberschmidt (12) não conseguiram infetar $N$. glutinosa com o virus da faixa das nervuras. Pelo contrário, em nossas experiências, esta planta se tem mostrado suscetivel aos "strains" deste virus por nós estudados.

N. glutinosa não mostra sintomas primários. Os sintomas secundários manifestam-se primeiramente como palidez das nervuras. Pos. teriormente, observa-se, nas folhas de meia idade desenvolvidas após a infeção, a presença de manchas de cor verde-escura sobressaindo-se do fundo verde-claro da folha e tambem faixas verde-escuras acompanhando as nervuras. Os sintomas não são muito acentuados e podem passar despercebidos a uma observação superficial. Quando as plantas infetadas se tornam idosas, os sintomas tendem a desaparecer.

A suscetibilidade desta espécie tem sido verificada em nossas experiências não só pela observação direta dos sintomas das plantas inoculadas como tambem por retroinoculações para plantas de fumo da variedade Turkish, efetuadas com o suco de $N$. glutinosa. Estas retroinoculações reproduziram a moléstia faixa das nervuras e foram repetidas diversas vezes. As inoculações de $N$. glutinosa já foram feitas com diversos "strains" do virus da faixa das nervuras. Em todos os ensaios efetuados esta planta foi infetada com facilidade.

No quadro IV reproduzimos os resultados de nossas inoculações com esta planta :

\section{QUADRO IV}

INOCULAÇAO DE $N$. GLUTINOSA COM O VIRUS DA FAIXA DAS NERVURAS.

\begin{tabular}{c|c|c}
\hline \hline \multirow{2}{*}{ N.* DO ENSAIO } & \multicolumn{2}{|c}{ N.o DE PLANTAS } \\
\cline { 2 - 3 } & inoculadas & infetadas \\
\hline 608 & 8 & 8 \\
650 & 10 & 10 \\
656 & 16 & 16 \\
\hline
\end{tabular}

Entre os outros suscetiveis deste virus merecem ainda menção os seguintes : 


\section{Nicotiana repanda:}

Não observamos sintomas primários. Os sintomas secundários manifestam-se como pintas cloróticas próximo ao ápice da folha e ao longo das nervuras de $1 .^{\mathrm{a}}$ e $2 .^{\mathrm{a}}$ ordem. Nas folhas médias e mais idosas, aparecem as pintas necróticas, que, a princípio, são de cor avermelhada. Este último sintoma é bastante caraterístico para esta espécie. Elas ocorrem ao longo das nervuras de $1 .^{a}$ e $2 .^{a}$ ordem.

\section{N. angustifolia $\left(^{*}\right)$ :}

Nesta planta o virus causa uma modificação de porte muito acentuada. O crescimento é paralisado depois que a planta foi infetada. As folhas mostram um forte mosaico, formado por áreas cloróticas que se localizam ao longo das nervuras de $1 .{ }^{\mathrm{a}}$ e $2 .^{4}$ ordem; as folhas se tornam repuxadas e mal conformadas. O seu tamanho é tambem menor que o de folhas sadias.

\section{N. Faniculata :}

Esta espécie merece menção especial, porque, em nossos ensaios, não apresentou sintoma algum de infeção a-pesar-de que retroinoculações para fumo reproduziram os sintomas da faixa das nervuras, mostrandonos assim que $N$. paniculata pode ser considerada uma planta portadora deste virus.

\section{N. digluta :}

Não mostra sintomas primários. Os sintomas secundários manifestam-se pelo aparecimento de pintas cloróticas, ao longo das nervuras de $2 .^{\mathfrak{a}}$ e $3^{\mathfrak{a}}$ ordem. Estas pintas mostram tendência para aparecer primeiramente nas proximidades do ápice. Nas folhas médias e inferiores, pode-se observar, às vezes, a presença de um mosaico formado por áreas verde-claras e verde-escuras. Pintas brancas podem estar presentes nas folhas de meia idade ou mais velhas.

\section{N. Langsdorfii :}

Sintomas primários não foram observados. Os sintomas secundários manifestam-se nas folhas novas como palidez das nervuras, muito acentuada no início. As folhas posteriormente desenvolvidas não mostram

(*) Veja chamada ${ }^{* *}$ ) da página 57. 
esse sintoma, mas apresentam pequenas manchas cloróticas nas proximidades do ápice. As folhas, que a princípio mostravam palidez nas nervuras, apresentavam mais tarde um mosaico fraco, formado por áreas cloróticas e verde-escuras. As áreas cloróticas destas folhas mostram tendência para ocorrer próximas aos bordos das folhas.

\section{N. rustica var. Brasilia :}

Não observamos sintomas primários nesta planta. Os sintomas secundários manifestam-se nas folhas novas pelo aparecimento de pintas cloróticas. Nas folhas mais velhas, pode-se observar "veinbanding" verde-escuro.

\section{Licopersicon esculentum:}

O tomateiro é uma planta que pode ser facilmente infetado pelo virus da faixa das nervuras.

Numa experiência preliminar, inoculamos 6 plantas de uma variedade cultivada de tomateiros e não observamos sintoma algum de infeção. Contudo, retroinoculações de algumas das plantas inoculadas para fumo reproduziram os sintomas da moléstia causada pelo virus da faixa das nervuras.

Posteriormente inoculamos 10 plantas de $L$. esculentum var. Marglobe, tendo sido observado como primeiro sintoma de infeção a palidez das nervuras das folhas novas. Cerca de 19 dias após a inoculação, as plantas inoculadas apresentavam um fraco mosaico nas folhas mais novas. Os sintomas são bastante fracos e tendem a desaparecer à medida que a planta envelhece. Este fato é tambem relatado por Smith (16), para o caso de tomateiros inoculados com o virus $\mathrm{Y}$.

\section{Lyocopsrsicon pimpinellifolium:}

Numa experiência preliminar inoculamos 10 plantas desta espécie. A moléstia não difere essencialmente do que acima relatamos para L. esculentum var. Marglobe.

\section{Solanum tuberosum :}

Inoculações preliminares efetuadas com plantas das variedades President e Green Mountain mostraram que o virus da faixa das nervuras causa lesões locais necróticas do tipo risca ("streak"), mosaico e rugosidade das folhas novas e necrose das folhas inferiores e médias, havendo tambem queda das folhas ("leaf drop streak"). Os sintomas na variedade Green Mountain são mais acentuados do que na variedade President. 
As plantas novas são mais facilmente infetadas que aquelas já desenvolvidas. Ainda não tivemos ocasião de observar os sintomas das plantas provenientes de tubérculos afetados.

\section{ETIOLOGIA}

A faixa das nervuras é indubitavelmente causada por um virus do grupo Y como apontado por Kramer \& Silberschmidt (12). É um virus facilmente transmissivel pelo suco das plantas afetadas, fornecendo em geral $100 \%$ de casos positivos.

Observações efetuadas no campo em plantas naturalmente afetadas, teem mostrado que o virus da faixa das nervuras não oferece proteção contra o virus de vira-cabeça (4). Tambem não existem relações de imunidade para com o virus da necrose branca ou couve (3). Tanto já observamos plantas primeiramente infetadas pelo virus da faixa das nervuras e que posteriormente são infetadas pelo virus da necrose branca ou couve, como tambem o caso inverso.

Em seguida, vamos descrever alguns ensaios que efetuamos sobre as propriedades físicas dos "strains" por nós estudados.

\section{Tolerância à diluição :}

No quadro $V$ reproduzimos os resultados dos ensaios efetuados. Por ele se vê que os nossos "strains" deste virus se mostravam ainda infetivos a uma diluição de 1:10.000. Este resultado não está em perfeita concordância com o de outros autores que se teem ocupado com o estudo dos virus deste grupo.

Smith (15) refere que o virus $Y$ produz raramente infeção a uma diluição maior que $1: 1.000$. Dykstra (5) trabalhando com alguns virus do grupo $Y$ achou que o virus do "veinbanding" tem uma resistência à diluição de 1:1.000 assim como o virus do "Stipple Streak", ao passo que o virus do "veinbanding" resiste a 1:900. Koch \& Johnson (10) acharam que tanto o virus $\mathrm{Y}$ como o virus do "veinbanding" resistem a 1:5.000.

Kramer \& Silberschmidt (12) acharam que a tolerância à diluição do virus da faixa das nervuras é de 1:500. Este resultado, deve em parte ser atribuido à maneira como aqueles autores fazem os testes de diluição ( $\left.{ }^{*}\right)$.

(*) Kramer \& Silberschmidt (12) fazem os testes de diluição a partir de um suco que denominam suco normal e que obteem por trituração de uma amostra de folhas com determinado peso, adicionada do mesmo peso em água. Em nossos ensaios denominamos suco normal aquele que obtemos por trituração $\theta$ prensagem manual das folhas sem adição de água. Corresponde mais ou menos ao "expressed sap" dos americanos. É a partir do nosso suco normal que efetuamos todos os nossos ensaios sobre propriedades físicas. 


\section{Ponto termal de inativação:}

Os nossos ensaios são incompletos a este respeito. Os resultados até agora obtidos mostram, contudo, que o ponto termal de inativação do virus da faixa das nervuras está entre $54-55^{\circ} \mathrm{C}$, o que concorda plenamente com os resultados obtidos por outros autores para o virus deste grupo. O nosso resultado está um pouco abaixo do obtido por Kramer \& Silberschmidt (12). Eles encontraram como ponto termal de inativação do virus da faixa das nervuras $60^{\circ} \mathrm{C}$.

Longevidade in vitro:

Os resultados de nossos ensaios sobre esta propriedade física do virus da faixa das nervuras mostram que a longevidade in vitro deste é de 72 horas. Este resultado concorda com aqueles obtidos por outros autores para os virus do grupo $Y$.

Kramer \& Silberschmidt (12) acharam que o "strain" do virus da faixa das nervuras por eles estudados tem uma longevidade in vitro de 48 horas. O número reduzido de plantas ensaiadas não fornece, porem, um resultado conclusivo.

\section{A transmissão da faixa das nervuras na natureza :}

Nada sabemos ainda sobre a transmissão natural da faixa das nervuras. Dos vetores já conhecidos de virus do grupo Y sabemos da existência no Estado de apenas Macrosiphum solanifolii. Este afídeo já foi encontrado em batatinha e tambem em fumo. Sobre o seu possivel papel como vetor desta moléstia nada podemos adiantar.

\section{DISCUSS $\tilde{A} O$}

O exame das propriedades físicas do virus da faixa das nervuras, os sintomas causados nos diferentes suscetiveis, a imunidade de Datura stramonium ao virus, etc., são fatos que mostram pertencer este virus ao grupo do virus $Y$ da batatinha. Os nossos trabalhos confirmam, pois, aquele de Kramer \& Silberschmidt (12) a este respeito. 


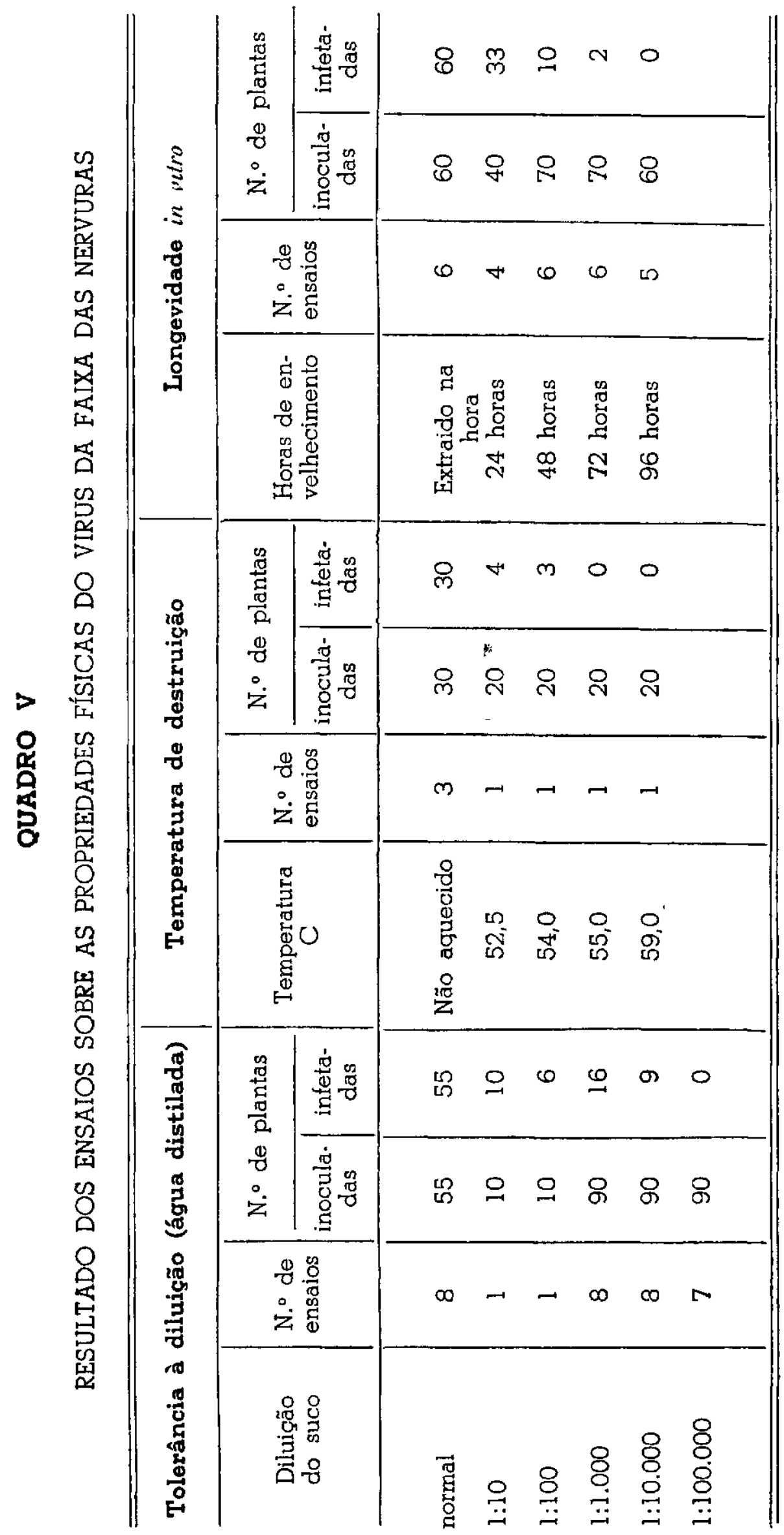


Entre diversos virus que pertencem ao grupo $Y$, os autores citados opinam que o virus do "veinbanding" dos americanos é o que mais se aproxima do virus da faixa das nervuras. Em suas considerações sobre a posição do virus da faixa das nervuras dentro do grupo $Y$, os autores citados comparam-no com o virus $A$, com o virus $P$ de Kohler (11) e com o virus $Y$ de Smith (14). Extranhamos que não tenham efetuado comparações com o virus do "Stipple-Streak", que é incluido por todos os autores dentro do grupo Y. Deixamos de o fazer por não termos conseguido a literatura sobre este virus.

Passemos a analisar novamente a posição do virus da faixa das nervuras dentro do grupo $Y$, à luz dos nossos trabalhos.

Concordamos com Kramer \& Silberschmidt que, conquanto haja alguma semelhança entre os virus $A$ e os outros virus do grupo $\mathbf{Y}$, é, contudo, facil de separá-lo não havendo possibilidade de confundí-lo com o virus da faixa das nervuras.

$\mathrm{O}$ virus $\mathrm{P}$ de Kohler já apresenta mais alguns pontos de semelhança com o virus da faixa das nervuras. Contudo, Kramer \& Silberschmidt julgam-no diferente deste virus, apontando as seguintes diferenças

1) O virus da faixa das nervuras não sofre inativação in vivo em plantas da variedade Samsoun.

2) $O$ seu ponto termal de inativação é cerca de $10^{\circ} \mathrm{C}$ mais elevado que $O$ do virus $P$.

3) $O$ virus da faixa das nervuras não infeta Nicotiana glutincsa.

Tambem não observamos a inativação in viso do virus da faixa das nervuras como verificada por Kohler para o virus P. Não trabalhamos, porem, com plantas da variedade Samsoun, a usada por este autor, mais sim com a variedade Turkish, que é do mesmo tempo.

Uma diferença de $10^{\circ} \mathrm{C}$ no ponto termal de inativação é de bastante significância para distinção entre dois virus. Kohler determinou que $\circ$ virus $\mathrm{P}$ tem um ponto termal de inativação de mais ou menos $50^{\circ} \mathrm{C}$, ao passo que Kramer \& Silberschmidt encontraram $60^{\circ} \mathrm{C}$ para 0 virus da faixa das nervuras. É preciso, porem, ser levado em conta que na maior parte das experiências efetuadas por estes autores, o ponto termal de inativação encontrado foi de $55^{\circ} \mathrm{C}$. Apenas em um teste efetuado com a variedade White Burley foi encontrado o valor de $60^{\circ} \mathrm{C}$. Nos nossos ensaios, encontramos, para ponto termal de inativação do virus da faixa das nervuras, a temperatura de $54^{\circ} \mathrm{C}$. A este respeito, são os nossos ensaios, porem, incompletos.

Em relação à não suscetibilidade de Nicotiana glutinosa ao virus da faixa das nervuras como verificado por Kramer \& Silberschmidt, temos a dizer 
que, em nossos ensaios, todos os "strains" deste virus infetaram $N$. glutinosa com facilidade.

Em resumo, podemos dizer que o virus $\mathrm{P}$ apresenta muita semelhança com os "strains" do virus da faixa das nervuras, por nós estudados, principalmente na sintomatologia em fumo. Já em batatinha, Kohler refere não ter observado nem risca ("streak") nem queda das folhas ("leafdrop"). Nos nossos ensaios observamos estes sintomas em batatinha, se bem que tenhamos trabalhado com variedades diferentes daquelas usadas por Kohler.

A nosso ver, a diferença nos sintomas observados em batatinha e a diferença no ponto termal de inativação mostram que os dois virus são distintos.

Comparando o virus da faixa das nervuras com o virus Y, Kramer \& Silberschmidt apresentam as seguintes diferenças:

1) Falta dos sintomas de amarelecimento do limbo entre as nervuras das folhas do fumo, sintoma esse observado por Dykstra (6) em planta de fumo afetada por $\mathrm{Y}$.

2) A ocorrência de faixas escuras longas e bem definidas nas folhas de variedades comerciais de $\boldsymbol{N}$. tabacum afetadas pelo virus da faixa das nervuras.

3) Os sintomas causados pelo virus da faixa das nervuras em batatinha são mais brandos que os causados pelo virus $Y$.

4) $\bigcirc$ virus da faixa das nervuras não infeta $N$. glutinosa.

As três primeiras diferenças apontadas são de carater sintomatoló. gico e se referem a variações qualitativas ou quantitativas de pouco valor. A nosso ver, estas diferenças teem valor relativo para separação.

Quanto à não suscetibilidade de $N$. glutinosa ao virus da faixa das nervuras, já referimos que nas nossas experiências este fato não foi confirmado.

Em inoculações que efetuamos com o virus da faixa das nervuras em batatinha, verificamos $\circ$ aparecimento de sintomas semelhantes aos causados pelo virus $\mathrm{Y}$, isto é : risca e queda das folhas inferiores. Contudo, não tivemos ainda ocasião de observar a progênie das plantas infetadas o que é de bastante valor para diagnóstico.

Comparando-se agora o virus da faixa das nervuras com o virus do "veinbanding" verificamos que a sintomatologia em fumo é bastante semelhante. Os sintomas descritos por Valleau \& Johnson (17) assemelham-se bastante ao que temos observado na mesma planta. Dykstra (5) refere-se apenas, sumariamente, aos sintomas causados pelo virus do "veinbanding" em fumo, que, contudo, se podem aplicar ao que temos 
observado. $\bigcirc$ virus do "veinbanding" tambem infeta $N$. glutinosa, não existindo tambem a este respeito nenhuma diferença.

Quanto às suas propriedades f́́sicas, o virus da faixa das nervuras não apresenta diferença alguma, seja com relação ao virus $Y$, seja ao virus do "veinbanding".

Concluindo esta nossa discussão, julgamos não ser possivel afirmar pelos nossos trabalhos, que o virus da faixa das nervuras é mais próximo ao virus do "veinbanding" do que ao virus $\mathrm{Y}$.

Segundo o nosso ponto de vista, não é mesmo possivel, à luz da literatura existente, fazer uma distinção satisfatória entre o virus do "veinbanding" e o virus Y. Passemos a discutir este ponto. Como já foi dito por Kramer \& Silberschmidt (12) os primeiros autores que se ocuparam com o estudo do virus $\mathrm{Y} e$ "veinbanding" consideram-nos idênticos. Posteriormente, outros investigadores, estudando os dois virus comparativamente, chegaram à conclusão de que, conquanto relacionados, eles não são idênticos. Este é o ponto de vista tambem esposado por Kramer \& Silberschmidt (12).

Estes autores não dizem, porem, até que ponto eles consideram os dois virus relacionados. É preciso sempre distinguir se há ou não relação e até que ponto vai essa relação. Assim, por exemplo, o virus $P$ de Kohler apresenta algumas relações com os virus do grupo Y. Contudo, ele é um virus diferente de $Y$, não oferecendo proteção contra $Y$ nas plantas com ele infetadas e mostrando assim que, provavelmente, não tem relação imunológica próxima com esse virus. $\bigcirc$ mesmo fato se dá com o virus $A$ que tambem causa moléstias com muitos pontos semelhantes àquelas causadas por $Y$ e "veinbanding". É, porem, um virus diferente daqueles, não apresentando relações imunológicas com o grupo.

Não é o caso acima o que se dá com o virus $Y$ e "veinbanding". Conquanto alguns autores reconheçam algumas diferenças entre eles, aliás de valor duvidoso, reconhecem, todavia, que se trata apenas de diferença entre "strains" do mesmo virus.

Baseados nos trabalhos existentes, podemos dizer que as diferenças consignadas entre o virus $Y$ e "veinbanding" se resumem no seguinte:

1) $O$ virus $Y$ é mais facil de transmitir pelo suco que o "veinbanding".

2) $O$ virus $Y$ causa sintomas mais acentuados que o "veinbanding" em certas variedades de batata, fumo e pimentão.

3) $O$ virus $Y$ não mancha as flores da Petunia como o "veinbanding". 
Koch \& Johnson (10) referem que Salanum nigrum se mostrou imune a $Y$ e suscetivel ao virus do "veinbanding". Smith (16), porem, relata que $S$. nigrum é tambem afetado pelo virus $Y$, desenvolvendo sintomas iniciais que mais tarde desaparecem, permanecendo então esta planta como portadora.

O exame das diferenças registadas entre os dois virus, mostra-nos que elas constituem, sobretudo, variações na intensidade dos sintomas causados. A nosso ver, estas teem pouco valor para separação.

Por outro lado, os pontos de semelhança entre os dois virus são muito fortes :

1) Semelhança na sintomatologia causada nos diferentes suscetiveis, apenas, com divergências em intensidade. Koch \& Johnson (10) relatam que estudaram os dois virus comparativamente em oito hospedeiras diferenciais, não tendo encontrado nenhuma diferença no comportamento destes dois virus nestas plantas.

2) As propriedades físicas encontradas para estes dois virus são as mesmas.

3) As relações de imunidade são perfeitas.

Dykstra $(5,6)$ verificou que o virus do "veinbanding" oferece proteção contra $Y$. Chester (1) tambem demonstrou que as reações serológicas entre "veinbanding" e $Y$ são positivas.

4) A identidade dos vetores.

Para concluir, queremos afirmar que sobre a relação entre estes dois virus pensamos com Dykstra (5), que diz serem os virus $Y$ e "veinbanding" "strains" dum mesmo virus e propõe sejam designados por $Y$.

\section{SUMMARY}

The present paper deals with the virus disease of the tobacco plant recently described by Kramer \& Silberschmidt (12) under the name "faixa das nervuras" (veinbanding).

New host plants are added to the list of suscepts, as follows: Nicotiana repanda Willd., N. angustifolia ("), N. Gossey Domin, N. Sanderae Hort. ex. W. Watson, N. glulinosa L., N. longiflora Cav., N. paniculata L., Lycopersicon esculenlum Mill., L. pimpinellifolium Mill., and Cyphomandra betacea Sendt.

Datura stramonium L., already studied by Kramer \& Silberschmidt (12) and Nicotiana glauca Grah., Nicandra physaloides Gaertn., Solanum nodiflorum (**), S. nigrum L., Lactuca saliva L., Brassica oleracea L., Vigna sinensis Endl. var. Black., and Dolichor lablab L., var. purpurens were found not to be susceptible to the virus.

(*) This species was received with this name from the Division of Tobacco and Plant Nutrition, U.S.D.A.

${ }^{* *}$ ) One plant of $S$. nodiflorum out of 22 which were inoculated gave symptoms of veinbanding. However as no backinoculation was made it can not be stated with certainty if it was truly affected by this virus. 
The symptomatology on tobacco described by the above mentioned authors agrees as a whole with which has been observed that is : clearing of the veins, chlorotic spotting and veinbanding. In addition it is stated that the white necrotic spotting found associated with the disease on certain tobacco varieties, v. g. Sumatra and Turkish must be attributed to the same virus.

On potato plants of the varieties President and Green Mountain the virus causes local streak-like symptoms followed by chlorotic mottling of young leaves. Late symptoms take the form of leaf-drop streak.

The virus of "faixa das nervuras" is easily transmissible through the sap giving practi. cally $100 \%$ of success. The physical properties of the virus are: tolerance to dilution 1:10.000, thermal death point $54^{\circ} \mathrm{C}$. and logevity in vitro 72 hours. No vector of the virus is known.

The statement of Kramer \& Silberschmidt (12) that the virus of "faixa das nervuras" belongs to the group of the potato virus $\mathrm{Y}$ is confirmed. A discussion is given about the position of the virus within the group. Our results do not permit to state that the virus is more related to the veinbanding virus as claimed by these authors.

It is also pointed out that the differences found in the litterature between the $Y$ and veinbanding viruses are slight, justifying in the maximum the separation of both ${ }_{r}$ but as strains of the same virus.

\section{LITERATURA CITADA}

1. Chester, K. Starr. Serological studies of plant virusэs. Phytopath. 27:903-912 1937

2. Costa, A. S. e J. Franco do Amaral. Nota preliminar sobre uma moléstia das folhas do fumo causada por Bolryohasidium solani (Pril. \& Del.) Donk. Revista da Agricultura. Piracicaba. 14:389-397, fig. 1-9. 1939.

3. Costa, A. S., A. R. Lima, e R. Forster, "Necrose branca", uma moléstia de virus do fumo (Nicotiana taliacum L.) e "fumo couve" como sintoma tardio. Jornal de Agronomia. Piracicaba. 3:1-26, fig. 1-24. 1940.

4. Costa, A. S. e R. Forster, Identidade do virus de vira-cabeça e sua inclusão no grupo do virus do "spotted wilt". Bragantia. 1:491-516, fig. 1-19. 1941.

5. Dykstra, T. P. Comparative studies of some european and american potato viruses. Phytopath. 26:597-606. 1936.

6. Dykstra, T. P. Studies of viruses infecting european and american varieties of the potato Solanum tuberosum. Phytopath. 29:40-67, fig. 1-7. 1939.

7. Holmes, F. O. Inheritance of ability to localize tobacco-mosaic virus. Phytopath. 24:984-1002. 1934.

8. Johnson, J. A tobacco hybrid useful for virus studies. American Jour. of Botany. 23:40-46. 1936.

9. Koch, Karl Lee. The nature of potato rugose mosaic. Phytopath. 23:319-342, fig. 1-4. 1933.

10. Koch. Karl Lee e J. Johnson, A comparision of foreign and american viruses. Ann. Appl. Biol. 22: 37-54, pl. 3-5. 1935.

11. Kohler, E. Uber ein "Veinbanding-Virus" der Kartoffel. Phytopath. Zeitschr. 10:17-29. 1937.

12. Kramer, M. Karl e Silberschmidt. A "faixa das nervuras", uma doença de virus do fumo encontrada no Estado de S. Paulo. Arquivos do Instituto Biölógico. 11:165-187, Est. 39-41. 1940. 
13. Lima, A. R. e A. S. Costa. Variedades de fumo resistentes a vira-cabeça. Revista da Agricultura. Piracicaba. 15:133-140, fig. 1-2. 1940.

14. Smith, K. M. On the composite nature of certain potato virus diseases of the mosaic group. Proc. Roy. Soc. B. 109:251-267. 1931.

15. Smith, K. M. Em Recent advances in the study of plant viruses. J. \& A .Churchill. London. 1933.

16. Smith, K. M. Em Textbook of plant virus diseases. P. Blackiston's Son. \& Co. Philadelphia. 1937.

17. Valleau, W. D. e E. M. Johnson, Relation of some tobacco viruses to potato degeneration. Kentuchy Agri. Exp. Sta. Bull. 309:475-507, fig. 1-5. 1930.

18. Valleau, W. D. e E. M. Johnson," Tobacco diseases. Kentucky Agri. Exp Sta. Bull. 362: 1-62, fig. 1-28. 1936.

\section{EXPLICAÇÃO DAS FIGURAS}

Figura 1 - Planta da variedade Sumatra afetada pela faixa das nervuras e mostrando as pintas necróticas brancas.

Figura 2 - Folha da variedade Amarelinho, mostrando faixa das nervuras.

Figura 3 - Folha de planta da variedade Sumatra, mostrando as numerosas manchas cloróticas arredondadas. Nas proximidades do ápice há início da faixa das nervuras.

Figura 4 - Folha da planta da variedade Sumatra, mostrando faixa das nervuras e pintas necróticas brancas.

Figura 5 - Folhas de planta da variedade Sumatra, mostrando as pintas necróticas brancas.

Figura 6 - Folhas de plantas da variedade Sumatra, mostrando os sintomas da necrose branca (A) e das pintas necróticas brancas (B).

Figura 7 - Folhas de meia idade de plantas da var. Turkish, mostrando as manchas cloróticas arredondadas.

Figura 8 - Solanum luberosum var. Green Mountain. Folha inoculada com o virus da faixa das nervuras, mostrando os sintomas locais.

Figura $9-S$. Luberosum var. Green Mountain. Folha [de planta afetada, mostrando sintomas sistêmicos. 
Composto e tmpresso na TIPOGRAFIA SIQUEIRA

SALLES OLIVEIRA \& CIA. LTDA.

$S$ A $O \quad P A U$ L 


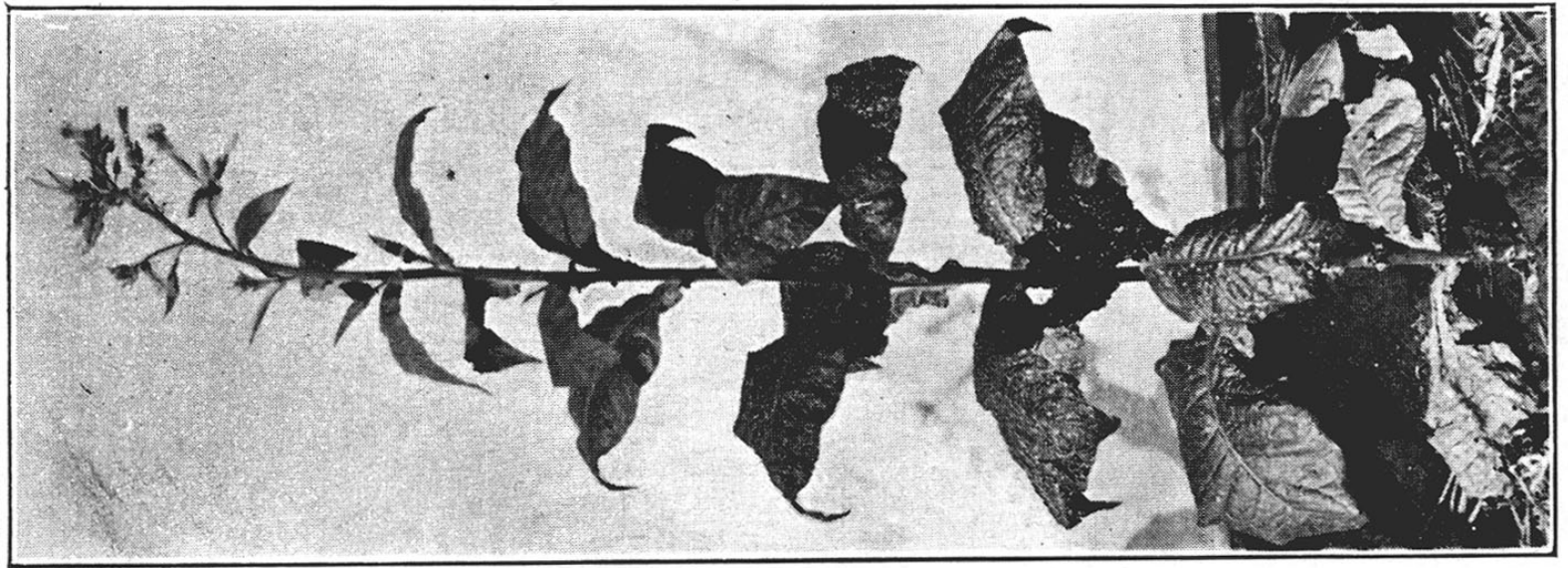

ت

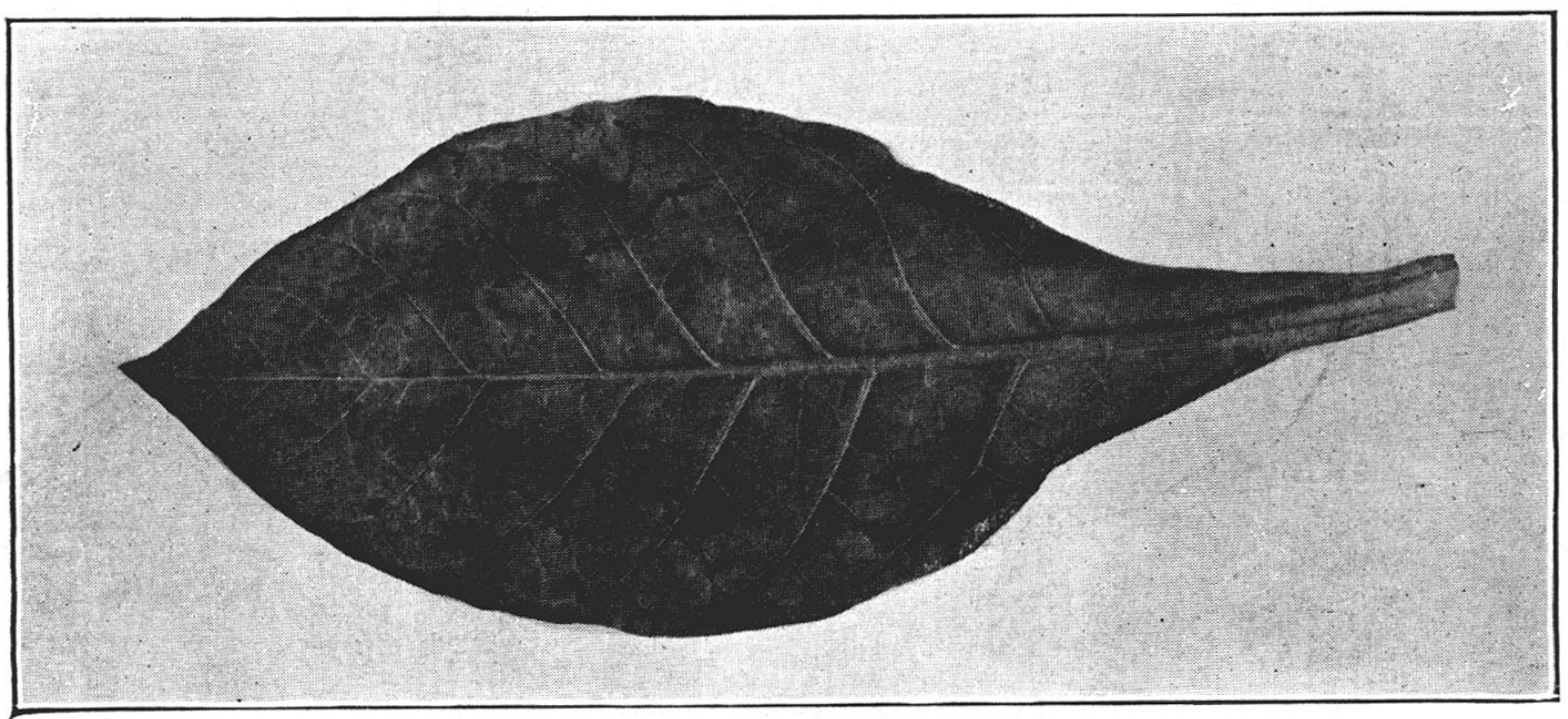




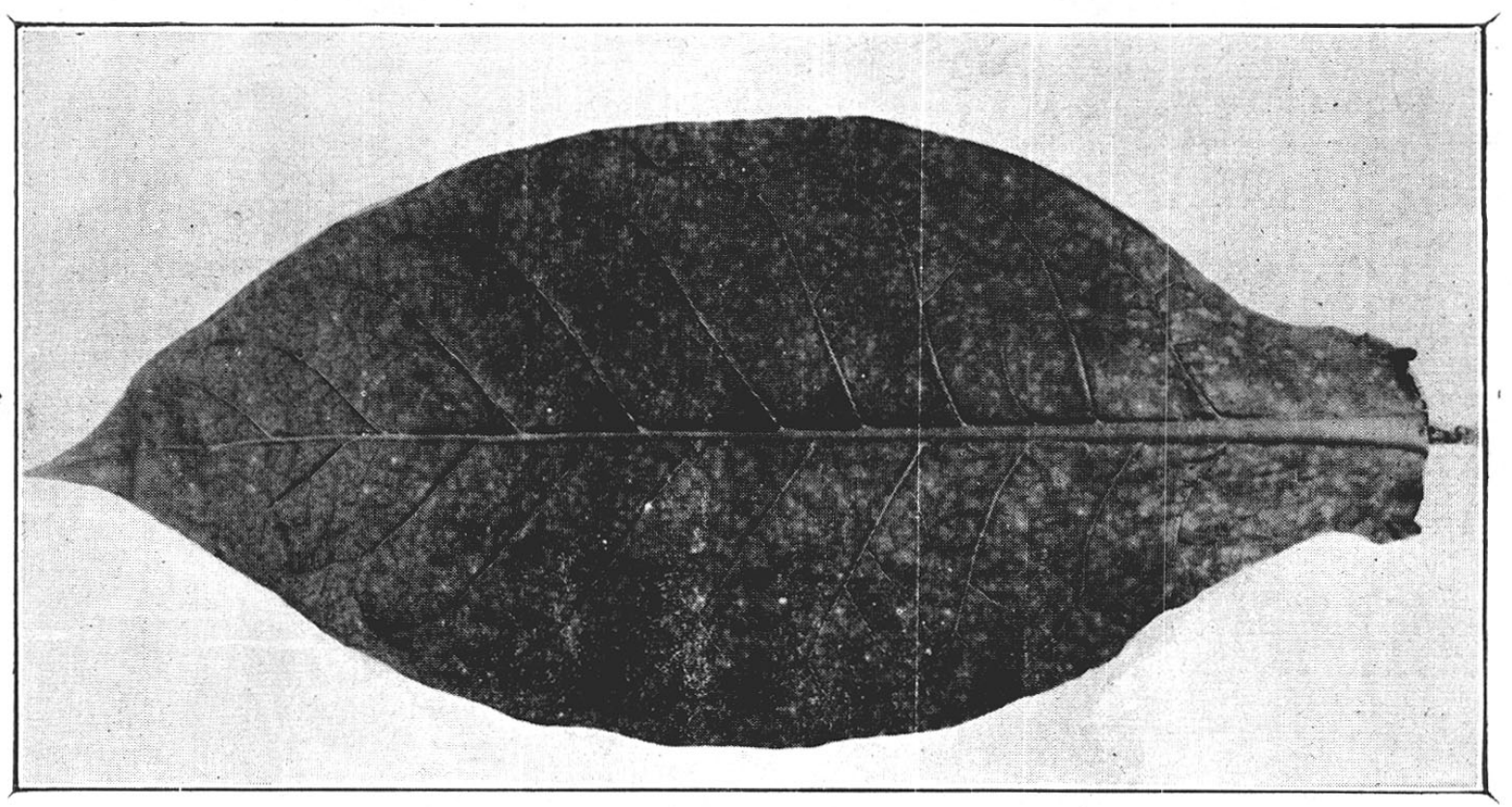

象

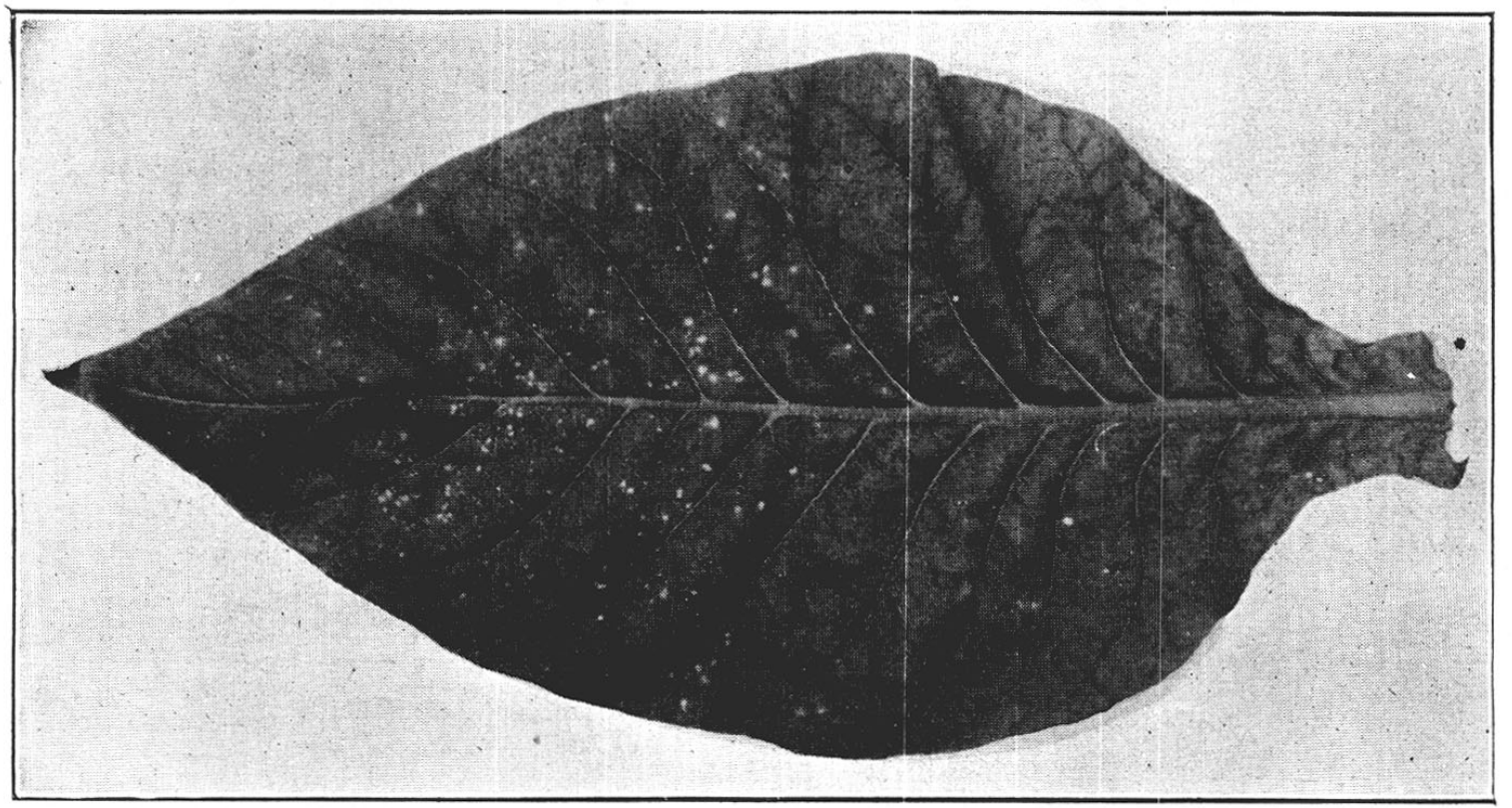

". 


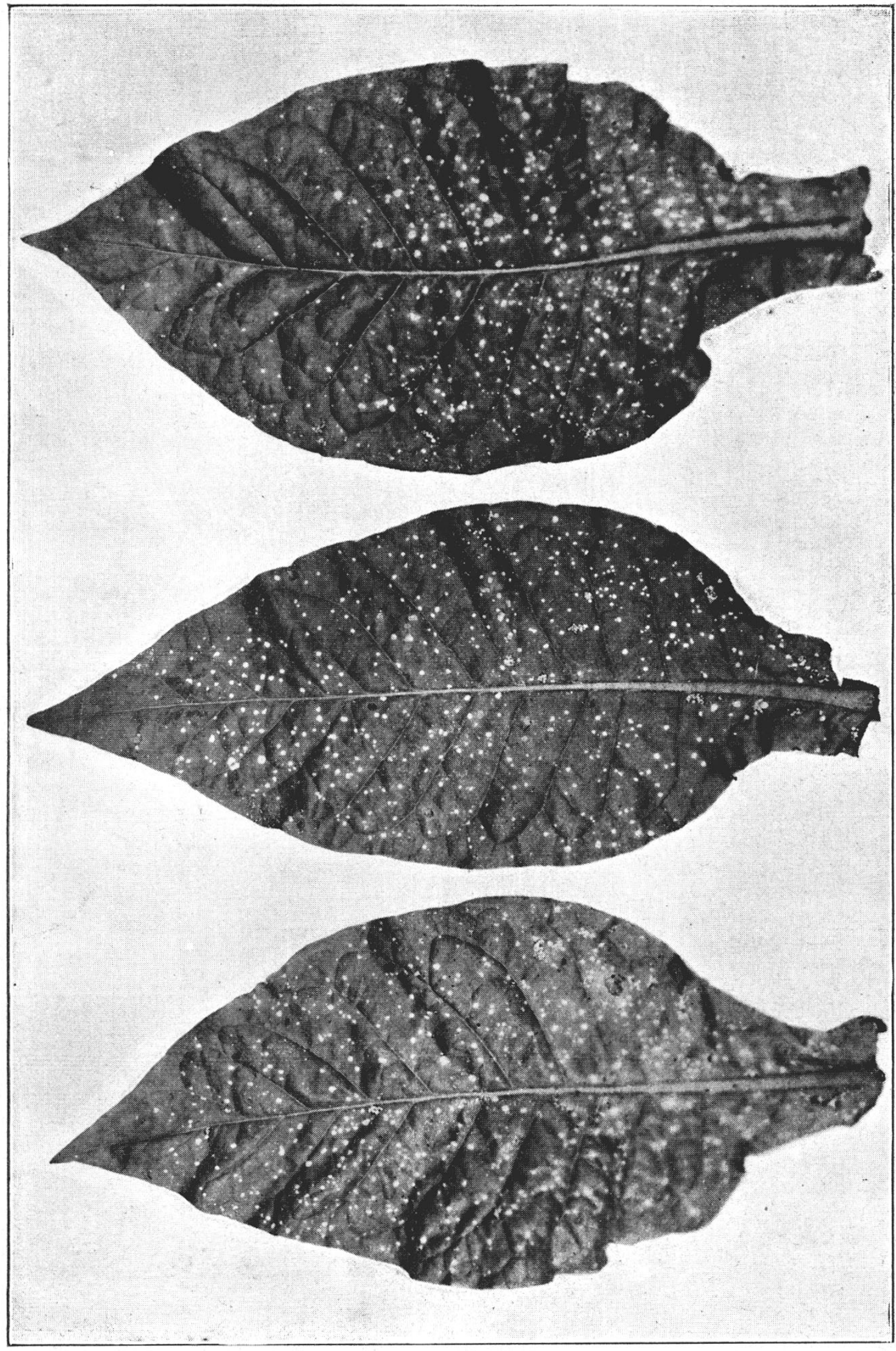

in 


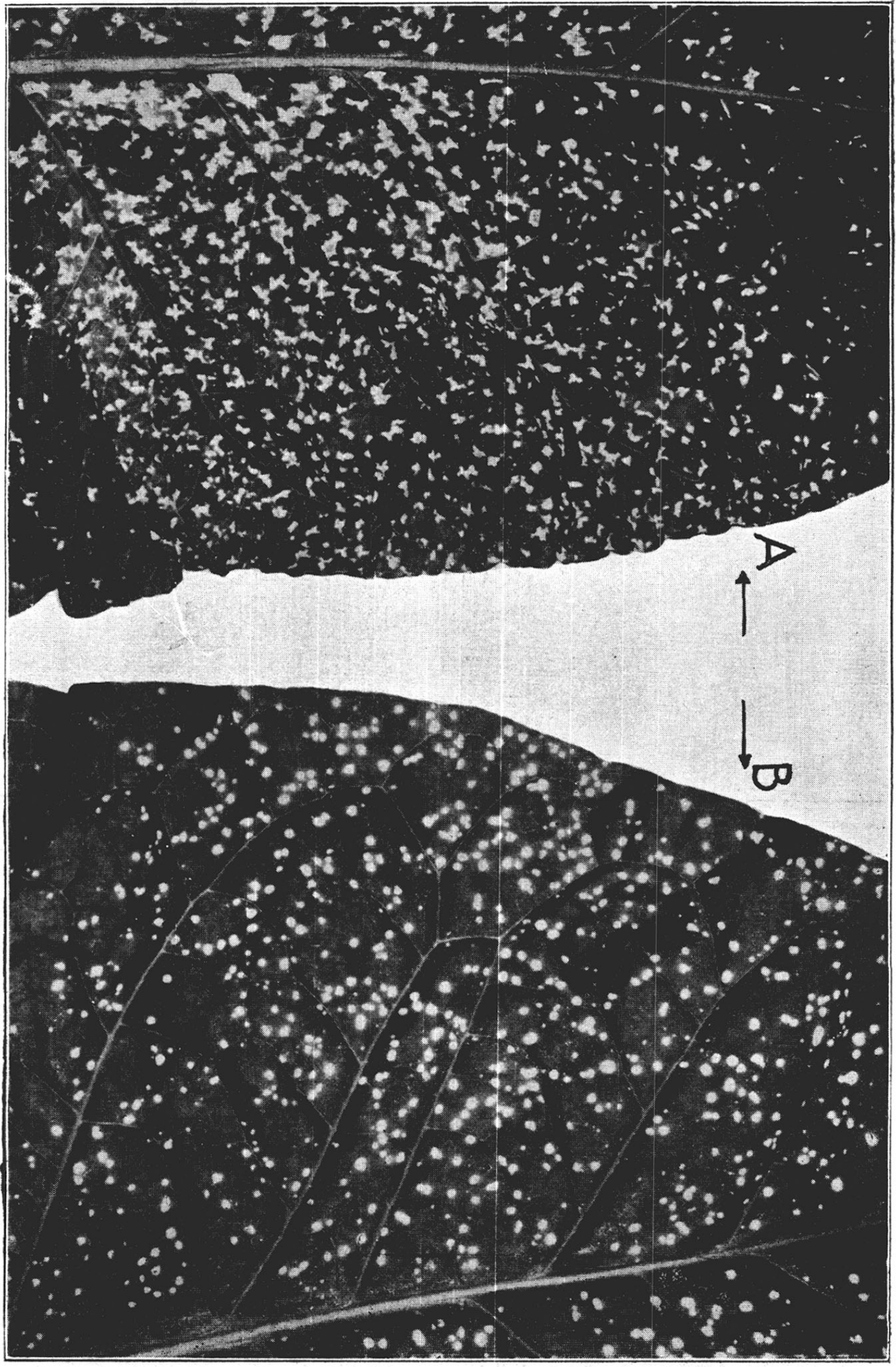




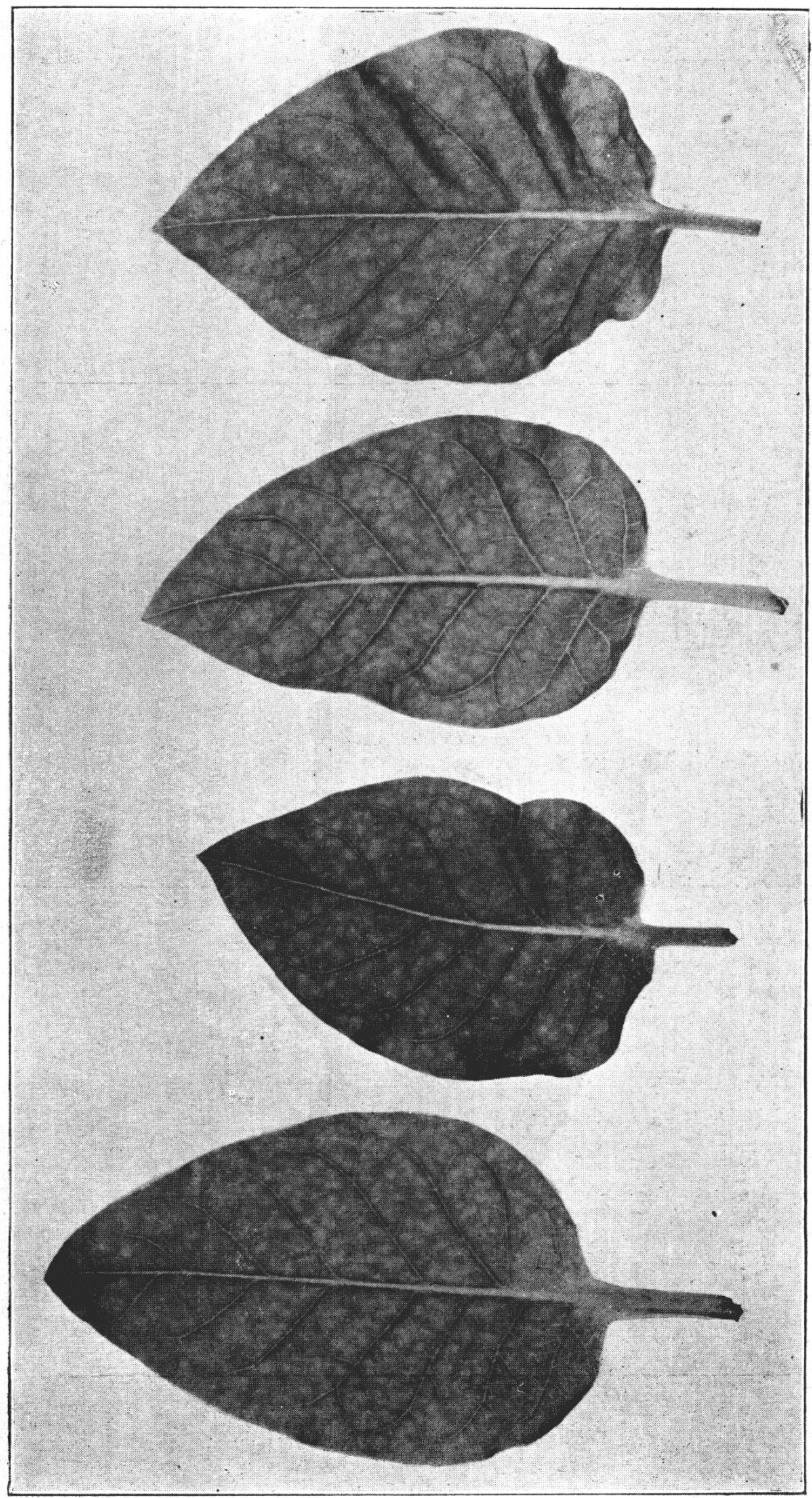

is 


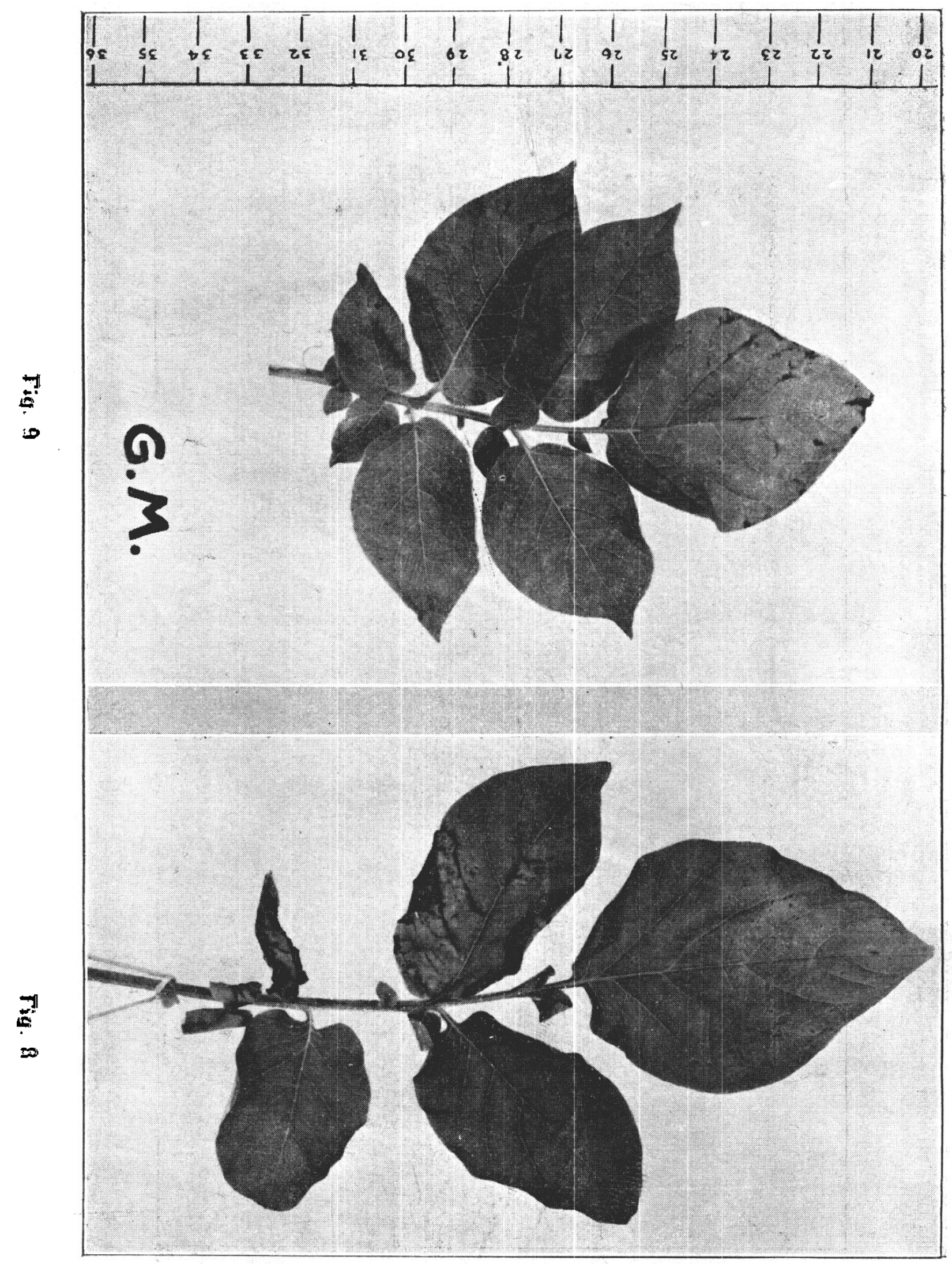

